\title{
Response of arbuscular mycorrhizal mungbean plants to ambient air pollution
}

\author{
${ }^{1 *}$ G. Nasim; ${ }^{2}$ R. Bajwa; ${ }^{3}$ A. Hakeem \\ ${ }^{1}$ Department of Plant Sciences, University of Tennessee, 2431- Joe Johnson Drive, Knoxville, TN, 37996-4561, USA \\ ${ }^{2}$ Department of Mycology and Plant Pathology, University of the Punjab, Lahore-54590, Pakistan \\ ${ }^{3}$ Department of Entomology and Plant Pathology, University of Tennessee, 2431- Joe Johnson Drive, Knoxville, \\ TN, 37996-4561, USA \\ Received 13 March 2007; $\quad$ revised 12 May 2007; $\quad$ accepted 5 June 2007; $\quad$ available online 20 June 2007
}

\begin{abstract}
The experiments were conducted in open top chamber system installed at the University of the Punjab, Quaid-e-Azam Campus, Lahore, Pakistan. The mungbean (Vigna radiata (L.) Wilczek var.M28) seeds were sown in earthen pots and were kept in filtered air, unfiltered air and ambient air. The ozone concentration was monitored daily during $1000 \mathrm{hrs}$ till $1600 \mathrm{~h}$. The data for light intensity and relative humidity was also regularly collected. The sets of plants growing in FA chambers (without ozone and dust particles) responded well as regards growth and yields are concerned. Unfiltered air reduced the number of nodules, their biomass and nitroginase activity in mungbean plants. The present study documents that the species of mycorrhizal fungi sensitive to tropospheric ozone failed to reproduce in ambient air and unfiltered air chambers (without dust particles). Out of a total of 24 species, eighteen species belonged to the genus Glomus, two each to Sclerocystis, to Acaulospora and one each to Gigaspora and Scutellospora. The total number of species was variable during the growth phase. The total number of species reduced in soil of UFA chambers with the passage of time. Species richness reduced to almost half in UFA plants as compared to FA plants. Species of the Genus Glomus were highly abundant species at various harvests in all air treatments. Amongst most abundantly recovered Glomus species were G. fasciculatum, G. mosseae, G. aggregatum, G. caledonicum, G. deserticola, G. geosporum, and G. monosporum. The pattern of abundance kept on varying at various harvests for different air and mycorrhizal treatments. In the case of plants of UFA treatment, only two species of Glomus were abundant namely G. fasciculatum and G. geosporum. Species of Acaulospora and Gigaspora in particular and Scutellospora and Sclerocystis in general were sensitive to polluted air.
\end{abstract}

Key words: Atmospheric pollutants, nitrogen dioxide, ozone, species richness, mungbean

\section{INTRODUCTION}

Ozone and nitrogen dioxide are major elements of urban smog that can affect plant growth and health. Negative impacts include reduced growth and seed production, and increased susceptibility to insects and disease (Lefohn, et al., 1997; Samuelson and Kelly, 2001; Castagna, et al., 2001). Long-term ozone stress may lead to changes in species composition and biodiversity (Burroughs, 2001; Ranieri, et al., 1996 and 2000; Crutzen, 2002; Allen and Rincon, 2003). Most plants form mycorrhizae, and the role of AM symbiosis in mediating plant responses to atmospheric change may be an important consideration in predicting effects of atmospheric pollutants on plants in agricultural lands and managed ecosystems (Shafer and Schoeneberger

*Corresponding Author Email: gnasim@utk.edu Tel./Fax: 924292318467
1991). Although the effects of atmospheric pollutants on mycorrhizal symbiosis have received some study in recent decades (Fitter, et al. 2000, Egerton-Warburton, et al., 2001, 2002), most research on ozone and mycorrhizae has involved coniferous plants and ectomycorrhizae. Less information is available regarding how ozone or nitrous pollutants affect arbuscular mycorrhizal (AM) colonization of roots and growth of AM plants (Duckmanton and Widden, 1994, McCool 1984; McCool, et al., 1982, 1983). McCool (1979) reported that higher than normal concentrations of ozone inhibited the growth and spread of Glomus fasciculatum in a Citrus sp. Air containing higher than ambient concentrations of ozone reduced photosynthetic capacity and inhibited mycorrhizal formation (Heath 1980; Heath, et al., 1982). With exposure to $0.1 \mathrm{ppm}$ 
ozone for three months, root weight and intensity of mycorrhizal formation declined in the forage grass Festuca arundinacea (Ho and Trappe 1984). When it is came to dual symbiosis under such kind of environmental stresses the literature is even much scanty. There are very few reports like the one by Brewer and Heagle 1983 on Soybean inoculated with Glomus geosporum and Rhizobium simulataneously. They reported that the plants were less sensitive to adverse growth and yield effects of ozone in the presence of dual inoculation. Mungbean is widely used in India and Pakistan as a source of protein in daily diet. It is cultivated on vast areas in the region. The soils in mungbean fields naturally have AM fungi. There are about 40 species of these fungi reported by Nasim and Bajwa (2005) in the agricultural feilds of area. In the present study it were attempted to enhance Rhizobium inoculum levels in the ordinary unsterilized field soil, thus trying to duplicate the natural environment rather than setting the experiments in the sterilized conditions. At this time we thought this to be a more agriculturally useful approach than non-AM vs AM or Non-Rhizobium vs. Rhizobium one. It was focused to determined that if enhancing native Rhizobial colonization might affect mungbean resilience to ozone and $\mathrm{NO}_{2}$. The Rhizobium enhancement treatments has been provided to all the pots and the sets were compared between three air treatments. These objectives addressed three specific hypothesis that 1 : the mungbean plants kept in filtered air are better health wise and in yield responses, 2: The mungbean plants with dual inoculation perform better in polluted air and respond drastically to filtered air treatment and 3: the AM species which are more resilient to air pollution sporulate in polluted air treatment and the species richness of the sensitive one is reduced ultimately.

\section{MATERIALS AND METHODS}

The study was conducted in the Botanical Garden of Punjab University, Quaid-e-Azam Campus, Lahore (31 ${ }^{\circ}$ 35-00-N, 74²1-00-E), Pakistan, on a 21x15 m suburban site adjacent to agricultural fields. The experimental site was $1500 \mathrm{~m}$ from the nearest main road, $7 \mathrm{~km}$ from the nearest industry and about $7.5 \mathrm{~km}$ from the city center. Ambient ozone levels here during the study generally ranged between 40 and $80 \mathrm{ppb}$ and $\mathrm{NO}_{2}$ between 25 and $35 \mathrm{ppb}$. In preparation for planting, the site was cleared of vegetation, ploughed and leveled.

\section{Plant material and inoculum Certified seed of mungbean [Vigna radiata (L.)}

Wilczek var. M28] was obtained through the courtesy of Mutation Breeding Division of Nuclear Institute for Agriculture and Biology (NIAB), Faisalabad, Pakistan. Healthy looking seeds were sorted out by rejecting empty and shriveled seeds. Seeds were surface-sterilized in a mixture of $70 \%$ ethanol and $\mathrm{H}_{2} \mathrm{O}_{2}(1: 1 \mathrm{by} \mathrm{v}: \mathrm{v})$, washed several times with sterilized tap water, then allowed to soak in a beaker of sterilized water for $24 \mathrm{~h}$.

The inoculum of Rhizobium used in this experiment was obtained from National Agricultural Research Council (NARC), Islamabad, Pakistan. The inoculum was in the form of black powder, which included the culture of Rhizobium mixed with Sphagnum peat (an inert material). These seeds were then taken out of the water were moistened in sugar solution made in water (10\%). The seeds were then rolled in the inoculum and sown. About $600 \mathrm{~g}$ of inoculum is recommended enough for $40-45 \mathrm{~kg}$ of seeds. Eight seeds were then sown into each of 48 sterilized earthen pots ( $25 \mathrm{~cm}$ in diameter) at a depth of 2-3 mm on $2^{\text {nd. }}$ March 1998. The potting medium was an unsterilized field soil (fine-loamy) mixed with sand (medium-to-coarse, mined, sieved) in 3:1 ratio. The soilsand mix was air-dried and sieved (passed through $2 \mathrm{~mm}$ screen). This was mixed with thoroughly sieved good quality composted farmyard manure in 6:1 ratio by volume. The suitable moisture (18\%) was maintained for germination. Seedlings were grown outdoors in a wire house until they were thinned at 10 days. Half of the pots in each treatment were placed in filtered air chambers while the other half were placed in unfiltered air chambers.

\section{Air pollutant treatments}

Ten days after planting, pots were thinned to 4 plants per pot and pots were relocated for exposure to differing levels of air pollutants. Twelve plots were prepared, each $1.5 \mathrm{~m}$ in diameter, with 3 replicate plants of each treatment placed in each plot. Prior to placing experimental plants, each plot was excavated to a depth of $0.4 \mathrm{~m}$ and had a concrete barrier applied to its perimeter to prevent the entry of rodents and soil erosion during monsoons. Open-top chambers were constructed on eight of the plots. Circular angle iron frames were attached to the concrete at the tops of each of these eight plot and open-top chambers fitted into these frames.

The cylindrical shape of the chamber was produced by connecting two angle iron frames (each $1.5 \mathrm{~m}$ in diameter), by five $1.5 \mathrm{~m}$ long vertical angle iron bars. The frames were fabricated locally. The curved walls were covered with plastic sheet (PVC 1000 gauge 
sheeting; transatlantic plastics), apart from an aperture between two adjacent support bars (approximately 0.5 $\mathrm{m}$ across), which was covered separately to create a doorway. The plastic was used only for one growth season and replaced at the beginning of each season, as with age it becomes more opaque and brittle with exposure to ultraviolet light and pollutant gases. Single inlet centrifugal blowers (fan) and motors of appropriate specifications were obtained from local manufacturers and used to blow air through lengths of plastic drainpiping of 6"diameter that were connected to the individual chambers. Emcel air filters (dust or pre-filters and charcoal filters) were imported from U.K. Pre-filters remove dust or particulate matter form the air while charcoal filters remove various pollutant gases from the air as they are absorbed by the activated charcoal. An activated charcoal filter along with a pre-filter connected to a $3 \mathrm{HP}$ fan-motor was linked to a pair of chambers through a 6" diameter drain-piping bifurcated at the distant end, each leading to individual chambers of the pair and connected to a vertical manifold. Similarly a pre-filter connected to a 2HP fan-motor was also linked to a pair of chambers. A vertical manifold which was simply a perspex pipe of 6" diameter blocked at its top end and with a butter fly valve at its base (allowing for the adjustment and equalizing of the air flow into each chamber) was fixed inside the wall of the chamber and connected to in-coming drain-piping. Vertical manifold was studded with 2" diameter holes $30 \mathrm{~cm}$ apart along its length in two parallel rows. Two consecutive rows of holes alternated with each other. Two horizontal manifolds constructed with from plastic lay flat tubing (transatlantic plastics) were connected to two parallel pairs of holes in the vertical manifolds (at heights of 50 and $80 \mathrm{~cm}$ ) so that they would be expanded by the air pressure. Holes (2.0 cm in diameter) were punched at 20 $\mathrm{cm}$ intervals in the horizontal manifolds to allow the introduction of air blown through the piping system into the chambers. The horizontal manifolds were fixed so that these holes were oriented at 45 degrees to the horizontal and directed to wards the ground. The total volume of each chamber was $2.83 \mathrm{~m}^{3}$, and the flow rate of the air into each chamber averaged $8 \mathrm{~m}^{3} / \mathrm{min}$. The resulting airflow therefore gave approximately 3 changes per minute. Shading of motors, fans and filters with metal housing minimized any rise in temperature of air entering the chambers. Dust was washed from the outside of the chamber walls regularly.

Four of the open-top chambers (UFA) were fanventilated with ambient unfiltered air by passing air through a dust filter (to remove particulate matter). The remaining four open top chambers (FA) were supplied with the same air but after passage through an activated charcoal filter in addition to the pre-filter to remove dust. The remaining 4 un-chambered control plots (AA) were not ventilated or filtered but were simply exposed to ambient atmospheric conditions. The purpose of the filters was to remove ozone and $\mathrm{NO}_{2}$ from the atmosphere around the mungbean foliage. This system was constructed following the methods of Bell and Ashmore (1986) and Wahid, et al. (1995a, b) The open-top chambers were arranged in four pairs, with the remaining four unchambered plots located a row adjacent to the chambered plots. The four plots not supplied with fanblown air or chambers were control plots. The chambers were operated as closely as possible to the conditions prescribed under European Open-top Chamber Programme Protocol. Light intensity, air temperature and relative humidity were measured at plant height each day at 0800,1200 and $1600 \mathrm{~h}$ using a portable light meter (horticultural lux meter, model Dm-28, OGAWA Seiki Co., Japan) and temperature-humidity probe (thermohygrometer, model HI-8564, Hanna Instruments, USA) throughout the experiment. Micro-climatic measurements began when plants were transferred to the experimental plots. Transparent walls of the open top chambers were kept clean by washing regularly early in the morning in order to minimize any differences in the light levels between inside and outside the open top chambers.

Ozone and $\mathrm{NO}_{2}$ were continuously monitored in each air treatment during the course of experiment by wet chemical methods.

\section{Measurement of ozone}

Ozone concentrations in air were measured using the KI buffered method (Saltzman and Gilbert, 1959) on alternate days (three times per week). Air was sampled in the center of the experimental plots between 1000 to 1600 h. at crop height. This sampling height varied as the crop matured. Initially for the calibration a neutral buffered solution of potassium iodide (KI) was prepared containing $10.0 \mathrm{~g}$ of potassium iodide, $13.6 \mathrm{~g}$ of potassium di-hydrogen phosphate $\left(\mathrm{KH}_{2} \mathrm{PO}_{4}\right)$ and $14.2 \mathrm{~g}$ of anhydrous di-sodium hydrogen phosphate $\left(\mathrm{NaH}_{2} \mathrm{PO}_{4}\right)$ and final volume was made up to one litre with distilled water. A $0.05 \mathrm{~N}$ solution of iodine was then prepared by dissolving $16.0 \mathrm{~g}$ of potassium iodide and $3.17 \mathrm{~g}$ of resublimed iodide in distilled water and made the volume up to $500 \mathrm{~mL}$. By diluting $5 \mathrm{~mL}$ of this iodine solution to $100 \mathrm{~mL}$ with the original neutral buffered 
potassium iodide and $0.0025 \mathrm{~N}$ iodine solution was prepared.

The solutions of iodine concentration for the calibration were then prepared as follows:

- $0.8 \mathrm{~mL}$ of $0.0025 \mathrm{~N}$ iodine solution to $100 \mathrm{~mL}$ with $\mathrm{KI}$ solution $=2.54 \mathrm{ppm} \mathrm{I}_{2}$.

- $1.6 \mathrm{~mL}$ of $0.0025 \mathrm{~N}$ iodine solution to $100 \mathrm{mLwith} \mathrm{KI}$ solution $=5.08 \mathrm{ppm} \mathrm{I}_{2}$.

- $2.4 \mathrm{~mL}$ of $0.0025 \mathrm{~N}$ iodine solution to $100 \mathrm{mLwith} \mathrm{KI}$ solution $=7.61 \mathrm{ppm} \mathrm{I}_{2}$.

- $3.6 \mathrm{~mL}$ of $0.0025 \mathrm{~N}$ iodine solution to $100 \mathrm{~mL}$ with $\mathrm{KI}$ solution $=11.42 \mathrm{ppm} \mathrm{I}_{2}$.

The optical density of these solutions was then measured against the neutral buffered potassium iodide as reference, at a wavelength of $352 \mathrm{~nm}$ on a UV Spectrometer (Hitachi Model U-1100). A calibration graph was drawn for ozone estimation.

The air in the chambers was sampled by drawing the air through $10 \mathrm{~mL}$ of buffered potassium iodide solution at a known flow rate and for a known period of time. The ozone oxidized the potassium iodide to release iodine, the amount of iodine formed being measured on the spectrophotometer at $352 \mathrm{~nm}$. The optical density value was converted to ppm iodine using the calibration graph. Determination of Ozone concentration in ppm by substituting $\mathrm{I}_{2}$ values with $\mathrm{O}_{3}$ values in the equation derived below:

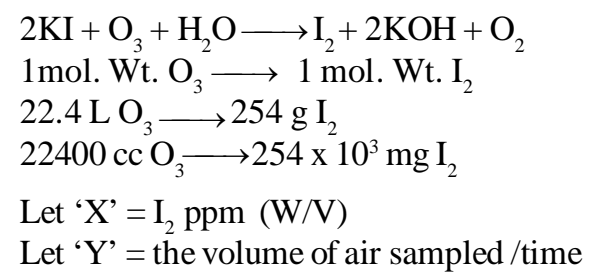

$\mathrm{O}_{3} \mathrm{ppm}(\mathrm{V} / \mathrm{V})=\frac{224 \times 10^{3}}{254 \times 10^{3} \mathrm{x}^{\prime} \mathrm{X}^{\prime} \mathrm{Y}^{\prime}}$

$\mathrm{O}_{3} \mathrm{ppm}=\frac{224 \mathrm{x}^{\prime} \mathrm{X}}{254 \mathrm{x}^{\prime} \mathrm{Y}^{\prime}}$

\section{Measurement of Nitrogen dioxide}

Nitrogen dioxide $\left(\mathrm{NO}_{2}\right)$ monitoring in open top was done over weekly periods in Chambers following Atkins, et al., (1978) using triethanol amine coated discs and their subsequent analysis calorimetrically. Diffusion tubes were exposed in triplicate at weekly intervals in the each of the 12 plots. Tubes were fixed on wooden rods anchored in the middle of the chambers at points which varied according to crop height during the course of the experiment at crop height, like for ozone.Concentration of $\mathrm{O}_{3}$ and $\mathrm{NO}_{2}$ inside the chambers was also monitored $3 x$ per month at different heights $(0.3,0.6,0.9$ and $1.2 \mathrm{~m})$, to gauge vertical pollution levels inside the chamber environment.

Nitrogen dioxide $\left(\mathrm{NO}_{2}\right)$ is measured using diffusion tubes developed at the Environmetal and Medical Sciences Division, AERE Harwell (Atkins, et al., 1978). Gas was samples passively by molecular diffusion along a tube to an absorbing medium. The absorbent used is triethanolamine (TEA) impregnated onto stainless steel mesh. $\mathrm{NO}_{2}$ is determined as nitrite ion colorimetrically. For a tube of known length and internal diameter with an efficient absorber at one end, the $\mathrm{NO}_{2}$ sampling rate may be calculated using Fick's Law of the unidirectional flow of gas through a mixture of gases under conditions of constant temperature. The temperature dependence of the diffusion coefficient is $0.2 \%$ per ${ }^{\circ} \mathrm{C}$ and the collection of gases in diffusion tubes is independent of pressure. The sampling rate of the tubes used here is calculated to be $62.3 \mathrm{~mL}$ of air per hour with a diffusion tube constant of 10437.8. The diffusion tubes comprise $7.1 \mathrm{~cm} \mathrm{x} 1.1 \mathrm{~cm}$ internal diameter acrylic tubes fitted with one coloured (blue or red) and one natural airtight polythene end-cap. Before used tubes are acid washed ( $5 \% \mathrm{HCl}$ ) thoroughly rinsed with distilled water and dried in an oven at $30^{\circ} \mathrm{C}$. One cm diameter discs which fit tightly inside the blue endcaps, are cut from 34 gauge stainless steel wire of mesh $0.224 \mathrm{~mm}$. They are also acid washed and dried before dipping in 50\% V/V triethanolamine/acetone solution. Discs are then placed on filter paper to allow the acetone to evaporate and thus leaving a fine coating of triethanolamine (TEA). Next two or three prepared discs are placed inside the blue polythene end-caps and these are refitted to the diffusion tubes, other end is also closed with natural polythene end-caps during transport and storage. It is important that prepared discs are placed inside coloured end-caps rather than other cap to prevent possible light induced reactions which may affect pollutant adsorption. During sampling the natural coloured end caps are removed and the tubes are mounted vertically, with absorbent uppermost and open end pointing down wards to prevent the entry of rain water and dust particles. Weekly sampling periods are employed and the starting and finishing times are recorded accurately. Duplicate tubes should be a minimum requirement to avoid any hazard and for accurate analytical analysis. 
Nitrogen dioxide $\left(\mathrm{NO}_{2}\right)$ is determined colorimetrically as $\mathrm{NO}_{2}$. One part distilled water, one part sulphanilamide reagent (20 g sulphanilamide $+50 \mathrm{~mL}$ concentrated orthophosphoric acid diluted to $1000 \mathrm{~mL}$ with distilled water) and one tenth part N-1-naphthyl-ethylenediamine-dihydrochloride (NEDA) reagent $(0.350 \mathrm{~g}$ NEDA in $250 \mathrm{~mL}$ distilled water) are added to each sample tube at the opposite end to the mesh collectors. After addition of chemical reagent, the open-end cap is closed. After $10 \mathrm{~min}$., shake the tubes gently and leave them for more than $20 \mathrm{~min}$. The nitrate ion is released from the mesh collectors in solution and deoxidizes the suphanilamide. The salt formed, become coupled with NEDA and a purple red azo dye is produced whose optical absorption is measured on a UV range spectrophotometer at $520 \mathrm{~nm}$ with a reagent blank in the reference cell. Standards were made up by dilution from $100 \mathrm{ppm}$ solution of 'analar' sodium nitrite and a range of 0.05 to $1.0 \mathrm{ppm}$ was sufficient to cover all samples. For a tube of known length and internal diameter with an efficient absorber at one end, the $\mathrm{NO}_{2}$ sampling rate may be calculated by using Fick's first law of the unidirectional flow of gas through a mixture of gases under conditions of constant temperature. The temperature dependence of the diffusion coefficient is $0.2 \%$ per ${ }^{\circ} \mathrm{C}$ and collection of gases in diffusion tubes is independent of pressure. Total microgram of nitrite was found from this analysis and parts per billion (ppb) $\mathrm{NO}_{2}$ was derived from this figure and the collection rate of the tubes thus:

$$
\begin{aligned}
& \text { ppb } \mathrm{NO}_{2}= \\
& \text { Sample } \mathrm{NO}_{2}^{-}(\mu \mathrm{g})-\text { blank } \mathrm{NO}_{2}^{-}(\mu \mathrm{g}) \times \frac{10437.8^{*}}{\mathrm{~T}(\mathrm{~h})} \\
& \text { *Diffusion tube constant }
\end{aligned}
$$

\section{Plant and fungal characters}

Plants were harvested three times during the experiment, at 30, 60 and 90 days after planting seeds. These times coincided with the prime of vegetative growth (Harvest I), the onset of flowering (Harvest II) and the end of growing season when the crop had ripened (Harvest III). For regular growth parameters, we recorded plant height, number of leaves per plant, Number of shoots per plant, Number of flowers per plant and Number of pods per plant. Plants in triplicate were harvested from each treatment and root systems were gently washed. Following parameters were recorded at the time of first, second and third harvest: Length of shoot and root (cm), number of nodules per plant, nodule fresh and dry mass, nitroginase activity, fresh weight of root and shoot (g), total fresh weight of plant (g) and oven dry weight of root and shoot (g). Yield parameters recorded at the time of final harvest (Harvest-III) were number of pods per plant, average number of seeds per pod, average number of seeds per pod, total Number of seeds per plant, total weight of seeds per plant, 1000 seed weight, and harvest index, which is defined as the ratio of grain yield to total plant mass (Sinclaire, 1998). Several mycorrhizal characters were assessed at each harvest: total, vesicular and arbuscular mycorrhizal colonization; and density and diversity of Glomalean spores. Roots were washed thoroughly and fixed in separate test tubes overnight or stored in mixture of formaline, acetic acid and ethyl alcohol (FAA) in 5:5:90 ratio. These were processed and stained following the methods of Phillips and Hayman (1970) with some modifications (Iqbal and Nasim, 1986). Stained root pieces (20 per slide) were examined under the microscope by randomly selecting the field and averaging the data for five such observations. AM spore extraction was done using the wet sieving and decanting technique of Gerdemann and Nicolson (1963) and Nasim and Iqbal (1991). Spores were mounted in water or stain (trypan blue in lactophenol) study under the microscope. Identification followed the synoptic keys of Morton (1988) and Schenck and Perez (1990).

\section{Acetylene reduction test}

The test was conducted at NIAB. Root systems along with rhizosphere soil were carried to NIAB, Faisalabad for further processing, for acetylene reduction test (Hardy, et al., 1973).

\section{Statistical analyses}

Test (DNMRT Standard error (SE), standard deviation (SD), Student's T test, analysis of variance (ANOVA) and Duncan's New Multiple Range) were performed to analyze the data following Steel and Torrie (1980) and Rosner (2000) using SPSS 10.0 (Carver and Nash 2000).

\section{RESULTS}

Open top chamber studies with mungbean

These open top chamber studies with mungbean were conducted March to June 1998.

\section{Microclimate measurements}

The results of the microclimate measurements are given in Fig. 1. On the average, the air temperature during the season was $1.11^{\circ} \mathrm{C}$ higher inside the open top 
chambers as compared to the outside ambient air. The relative humidity values were also slightly (1.19\%) higher inside the chambers as compared to that existing outside the chambers. On the contrary, light levels were reduced by $3.35 \%$ inside the chambers than those prevailing outside the chambers (Fig. 2). June being recorded the hottest and the driest month of the growth season.

\section{Pollutant monitoring}

Pollutant levels during the growth season remained much higher in the ambient environment as compared to the filtered air of the open top chambers. Average concentration of nitrogen oxide $\left(\mathrm{NO}_{2}\right)$ during the experimental season was $29.91 \mathrm{nl} \mathrm{l}^{-1}$ in UFA as compared to $11.7 \mathrm{nl} / \mathrm{L}$ in FA. Similarly mean ozone $\left(\mathrm{O}_{3}\right)$ concentration also followed the same trend. Up to $61.06 \mathrm{nl} / \mathrm{L}$ of $\mathrm{O}_{3}$ was recorded outside the chambers and $8.3 \mathrm{nl} / \mathrm{L}$ inside the chamber getting filtered air (Figs. 3 and 4).

\section{Plant vegetative growth assessment}

Three harvests were taken during the whole course of this experiment with mungbean. At the time of each harvest, the parameters recorded were as follows:

\section{Shoot length}

Data recorded on shoot length measurements (Fig. 5a) clearly indicate that shoot length was significantly enhanced in pollution free air (FA) right from the very beginning. This initial advantage over unfiltered ambient air was maintained throughout the growth period. Early growth depression and slower further increment is clearly evident in plants under ambient air condition. At first second and third harvest the average

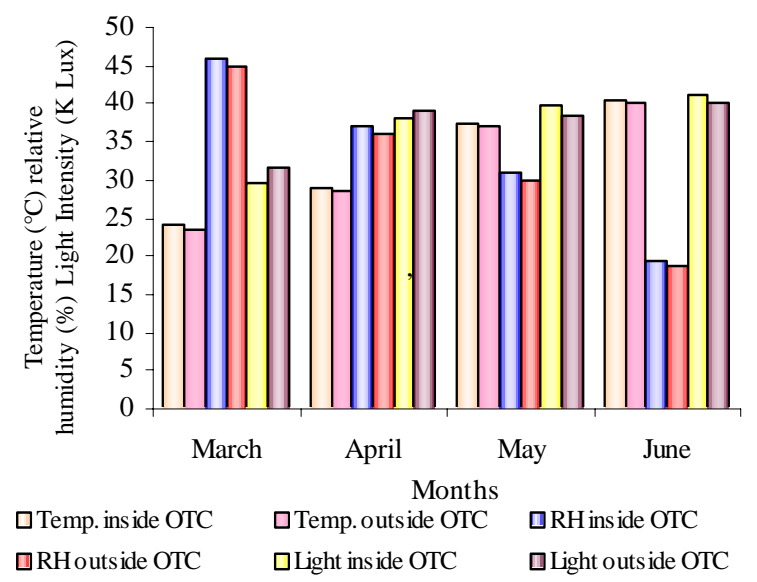

Fig. 1: Mean monthly temperature, relative humidity and light intensity inside and outside open top chambers in 1998 mungbean season estimated increase in shoot length of FA plants was 23.33, 23.77 and $28.86 \%$ respectively than their UFA counterparts. Thus the difference was maximum at the time of third harvest (Fig. 4a). The UFA plants had a slight advantage over AA plants but the values differed insignificantly in the two treatments.

\section{Shoot biomass}

The same trend was observed in shoot biomass values. The fresh and dry weights of plants kept in filtered, pollutant and dust free air (FA) showed alleviation from the early phases of growth (Fig. 5 c \& d). This trend persisted till the last harvest. The margin of difference also kept on increasing with the passage of time between FA and UFA plants. A shoot fresh weight reduction of 53.7, 55.17 and $65 \%$ was recorded in UFA plants. The oven dry weight of shoot of FA plants had a remarkable difference at the time of third harvest. The FA plants has $50.63 \%$ greater dry weight of shoot than that of UFA plants. The AA plants had minimum dry weights but the difference between UFA and AA plants was insignificant (Fig. 5d).

Number and biomass of nodules and nitroginase activity

As nodulation and $\mathrm{N}$-fixation studies are concerned various parameter recorded in this respect were, number of nodules per plant, fresh weight of nodules per plant and oven dry weight of nodules per plant. For the assessment of $\mathrm{N}$-fixation acetylene reduction test was also performed for all treatments. At first, second and third harvest the number of nodules per plant remained maximum for plants kept in pollutant and dust free air (FA) as compared to other two treatments (Fig. 5b).

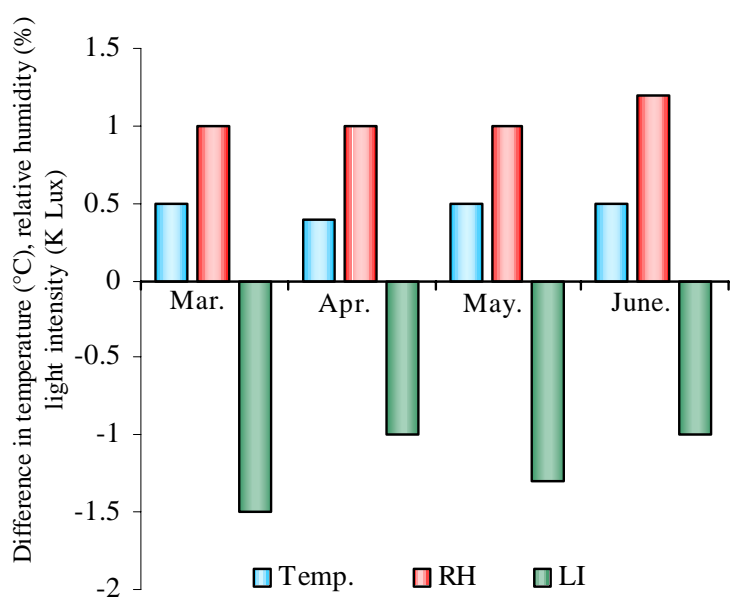

Fig. 2: Mean monthly differences in micro-climatic conditions inside and outside open-top chambers 


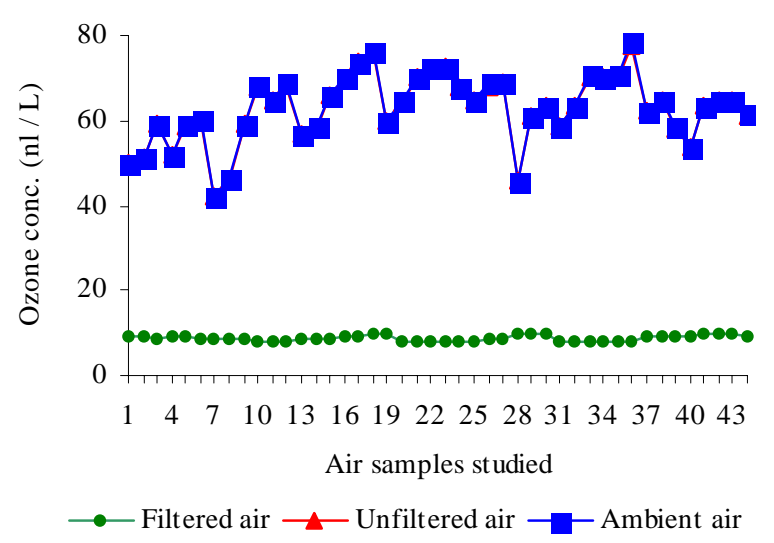

Fig. 3: Ozone concentration (nl/L) in filtered air and unfiltered air and ambient air plots during mungbean season. Ozone concentration represents a 6 h (10:00-16:00 h) mean

However, the number of nodules of FA plants had peak values (15.1 nodules/plant) at the time of second harvest. A reduction thereafter was observed in number of nodules in FA plants. A comparison drawn between FA and UFA plant yielded an enhancement of 20.34, 50.99 and $32.76 \%$ in number of nodules per plant of FA over UFA treated plants. While UFA plants has slighter advantage over AA plants but the difference in values was insignificant (Fig. 5b). Nodules of FA treated plants were bigger in size as is evident from the data on fresh and dry weight of nodules (Table 3). Fresh and oven dry weight of nodules per soybean plant showed highly promising results for plants kept in filtered air. The inoculum of Rhizobium was well suited to the soil and host thus showing significant figures in air treatments, which was free of pollutant gases and dust particles. These highest values were followed by the readings for UFA and AA Plants. Plants treated with UFA had slightly better results than AA plants. As far as the nitrogenase activity in nodules of experimental plants is concerned, an extremely high difference was observed for FA plants as compares to their UFA/AA counterparts, (Table 3). The amount of acetylene reduced per gram weight of nodules per hour was highly significant for FA plants.

\section{Plant's reproductive growth assessment}

Flowers appeared earlier in FA plants as compared to other air treatments. The flowering was delayed by 5 to 6 days as compared to UFA and AA treatments respectively. As far as the number of flowers per plant is concerned at the time of second harvest these were more than double the number produced by UFA or AA plants.

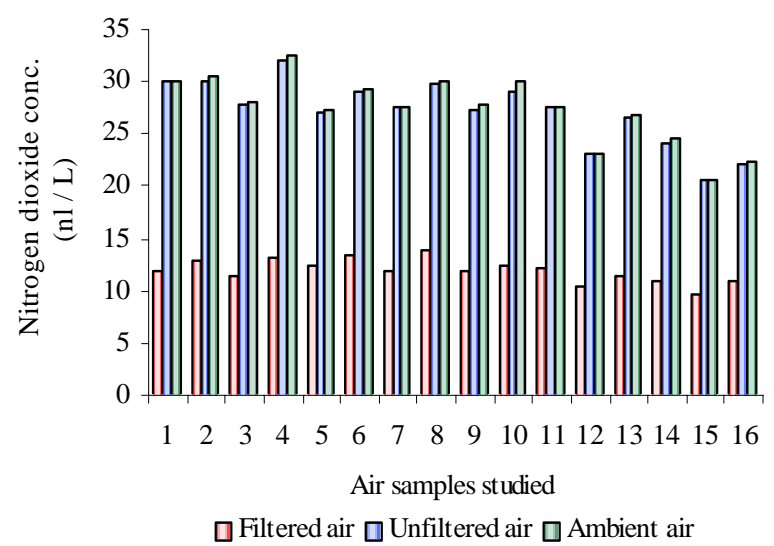

Fig. 4: Nitrogen dioxide concentration $(\mathrm{nl} / \mathrm{L})$ in filtered-air, unfiltered-air and ambient air plots during mungbean season. Nitrogen dioxide values are weekly means

UFA plants in this case had slightly higher number of flowers as compared to AA plants. These figures were also statistically significant at $\mathrm{P}<0.05$ level of significance (Fig. 6).

\section{Plants yield assessment}

Yield assessment was done at the end of the experiment. It is clearly evident from the figure 7 that the plants kept in open-top chambers ventilated with pollution free air responded extremely well. The yield parameters recorded at this stage were pods per plant, seeds per pod, seeds per plant and 100-seed weight. These determinations revealed highly significant effects of air treatments. Yield losses in terms of pods per plant were $48.38 \%$ for UFA and $64.52 \%$ for AA as compared to FA treatment. The total number of seeds reduced by $63.64 \%$ in UFA and $78.18 \%$ in AA sets (Fig. 7). The weight losses of $22.16 \%$ in UFA and $25.77 \%$ in AA in terms of 100 -seed weight were obtained. The substantial yield reduction observed in UFA and AA treatments as compared to FA plants were largely due to lesser number of pods per plant rather than the weight of seeds. Comparative yield losses in terms of number of seeds per plant among UFA and AA air treatments were also statistically significant with reduction of $42.47 \%$ and $43.83 \%$ respectively. As regards harvest index (HI) the FA plants showed highest HI values followed by UFA and AA plants (Fig. 8).

\section{Assessment of arbuscular mycorrhiza}

Evaluation of percentage arbuscular infection in roots indicates that the establishment of infection over the 
growth period was normal in all the air treatments. However, maximum initial advantage achieved in the intensity of infection was maintained till the last harvest. During the active functional phase of the mycorrhiza, the intensity of arbuscular infection was depressed by 43.1\% in UFA and 51.22 \% in AA treatments (Fig. 9a). The assessment of percentage of vesicular infection revealed that the typical pattern of development was followed in all the treatments (Fig. 9b). From very low level in the initial growth period, it gradually raised to highest. Persistently maximum levels however were recorded in FA treatments with infection reduction of 23.47 - 40\% in UFA and 26.53 - 50\% in AA treatments as compared to FA plants at all the harvests.

\section{Endogonaceous spore populations}

Total number of spores per $100 \mathrm{~g}$ rhizosphere soil was minimum at the time of third harvest for UFA and AA treatments and on the contrary for FA plants maximum spores were recorded at the time of final harvest.
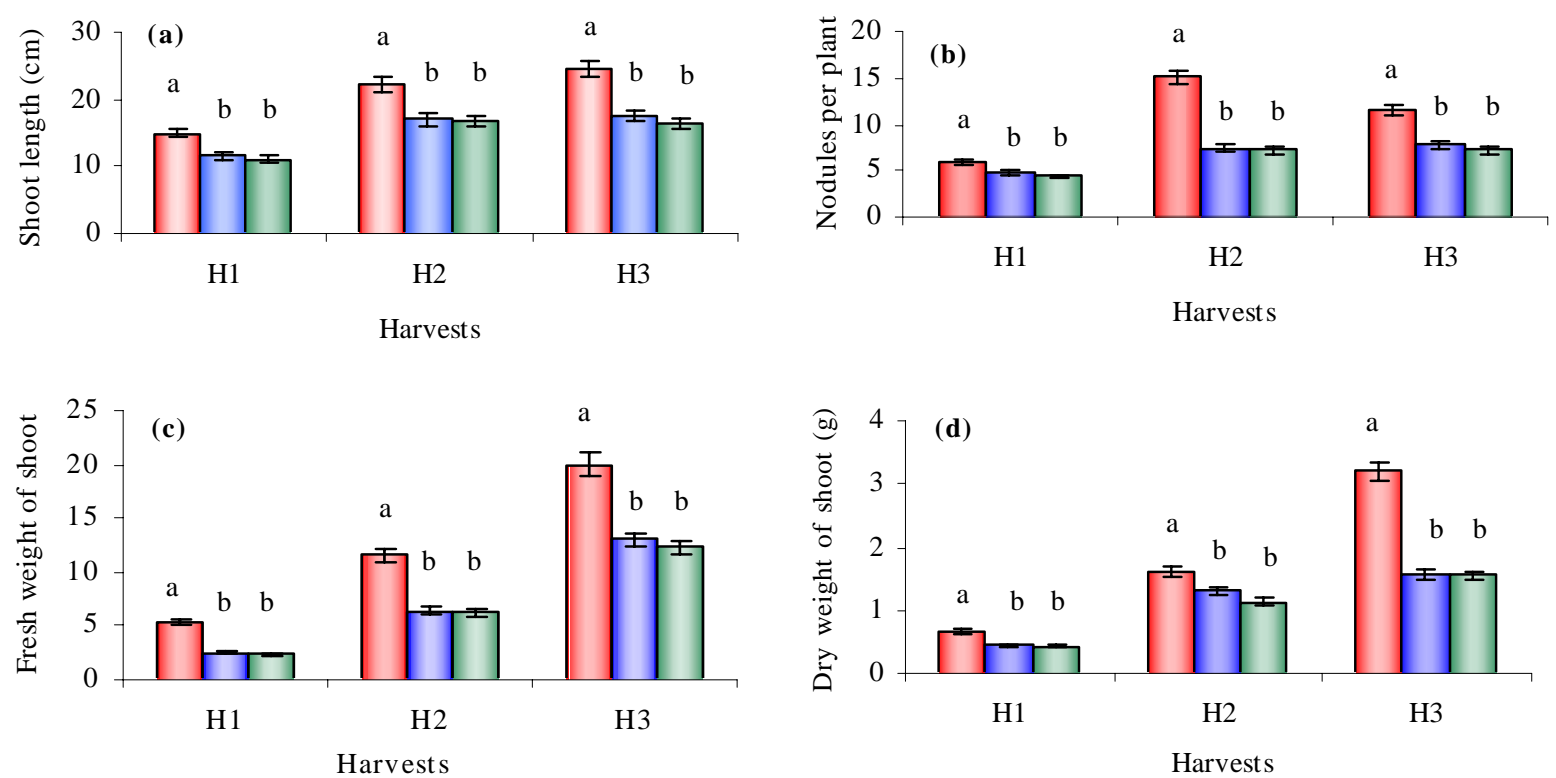

Fig. 5: Shoot length (a), number of nodules (b) and fresh and dry weight of shoot (c) and (d) in mungbean after various air treatments in open top chamber systems. Data bars with different letters are significantly different at $\mathrm{P}<0.05$

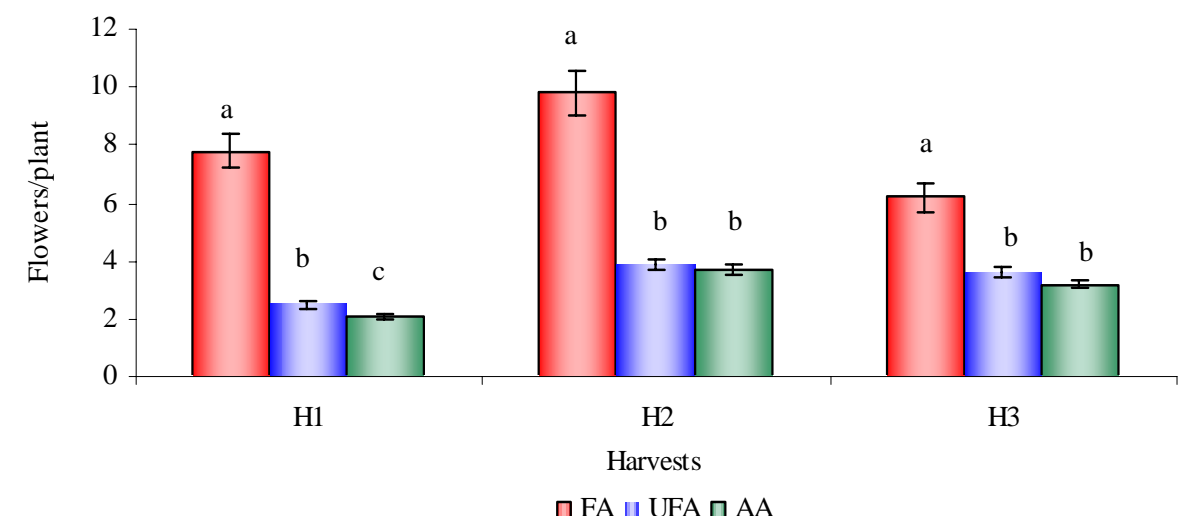

Fig. 6: Number of flowers in mungbean after various air treatments in open-top chamber systems. Data bars with different letters are significantly different at $\mathrm{P}<0.05$ 
It had maximum values at the time of third harvest. The number of spores gradually increased till it became maximum at the time of third harvest in FA treatment (Figs. 9 and 10). For UFA and AA plant the trend however was different, the spore number in the rhizosphere varies insignificantly in second and third harvest plants being slightly low as the time of second harvest. Spore formation at the time of third harvest was inhibited to more than $60 \%$ for UFA and AA plants as compared to FA sets which is clearly evident at the time of final harvest (Fig. 10). As regards the endogonaceous spore diversity, a total of 24 species of AM fungi were recorded as a result of screening of rhizosphere soil of mungbean plants kept in all the air treatments throughout the growing period (Table 1). However, the pattern of diversity changed from time to time and for various air treatments (Table 2).

\section{DISCUSSION AND CONCLUSION}

In the present investigation, new dimensions in the research of AM fungi have been discussed. The impact of air pollution on plants has been proved by a series of researches in the past (Cairney and Meharg, 1999). The positive role of arbuscular mycorrhizae in alleviating the effect of soil and sediment pollution has been shown variously in the literature (Oliveira, et al., 2001; Berreck and Haselwandter, 2001; Khan, et al., 2000; Chaudhry, et al., 1998; Leyval, et al., 1997). However, very scanty information is available in the literature related to the effect of polluted air on microbes especially AM fungi associated with roots of the plants. The influence of anthropogenically produced ozone, nitrogen dioxide and particulate matter on mungbean plants and their associated microflora has been a primary focus of this study. Comprehensive study was conducted focusing the issue and the results obtained were highly promising. The gaseous pollutants have been shown to reduce plant growth, yield and mycorrhizal development. This is inline with the studies of Reich, et al., (1988) and Ho and Trappe (1984). The present study was carried out in an open-top chamber system. This system has been found to be an excellent technique to assess the impact

Table 1: Variation in the total number of AM spore types at different stages of growth and in three air treatments

\begin{tabular}{cccc}
\hline \multirow{2}{*}{ Harvests } & \multicolumn{3}{c}{ Air treatments } \\
& AA & UFA & FA \\
\hline Ist Harvest & 16 & 15 & 19 \\
$2^{\text {nd }}$ Harvest & 15 & 13 & 20 \\
$3^{\text {rd }}$ Harvest & 14 & 14 & 24 \\
\hline
\end{tabular}

of ambient air pollution on growth and yield performance of wheat, rice and soybean, (Wahid, et al., 1995 a, 1995 b; Nasim, et al., 1995) in Pakistan. Very few studies have however been done on the impact of air pollution on vesicular arbuscular mycorrhizal status of test plants along with the study of growth parameters. Only a couple of investigations have been done on arbuscular mycorrhiza of wheat and soybean in the same set up, (Nasim, et al., 1995). According to Tiaz and Zeiger, (2006) experiments aimed at determining the impact of chronic exposures to low concentration of gases should allow plants to grow under near-natural conditions. One method is to grow plants in open-top chambers into which the gases are carefully metered, or where plants receiving ambient polluted air are compared with controls receiving air that have been scrubbed of pollutants, In the present study, results have shown that the climate inside the chambers hardly differed from that prevailing outside the chamber through out the season. This may be due to complete open-top design of the chamber. The chambers (FA and UFA) were connected with motor blower system to filter dust particles.

While FA chamber has an additional filter set up to filter ozone $\left(\mathrm{O}_{3}\right)$ and nitrogen dioxide $\left(\mathrm{NO}_{2}\right)$. The filters for gases showed high filtration efficiency through out the season. Another reason for the maintenance of pollution free environment inside FA chamber may be that, the conditions were not very windy at the experimental site resulting into a reduced ingress of outside air. In the present study as it was conducted in open top chamber system rather than being a fumigation experiment, the levels of gaseous pollutants like $\mathrm{O}_{3}$ and $\mathrm{NO}_{2}$ were not regulated. However daily monitoring was done which showed a concentration of around 5-8 ppb of $\mathrm{O}_{3}$ in FA and up to $80 \mathrm{ppb}$ in UFA chambers and ambient air. Similarly, for $\mathrm{NO}_{2} 10-12 \mathrm{ppb}$ in FA chambers and up to 40-45 ppb in UFA chambers and ambient air. Thus there were two drastically different sets of environmental conditions which ultimately affected plant growth, yield and mycorrhizal development. Besides $\mathrm{O}_{3}, \mathrm{NO}_{2}$ and other which were not measured on site like $\mathrm{SO}_{2}, \mathrm{NH}_{3}$, hydrogen peroxide $\left(\mathrm{H}_{2} \mathrm{O}_{2}\right)$ and peroxyacetyle nitrate cannot be excluded (Wahid, et al., 1995a and 1995b). The results of the present study show that various growth parameters related to vegetative growth such as plant height, number of leaves per plant, number of shoots per plant significantly increased in FA sets as compared to UFA and AA sets of plants. The differences became more pronounced in later phases of growth. 
G. Nasim, et al.
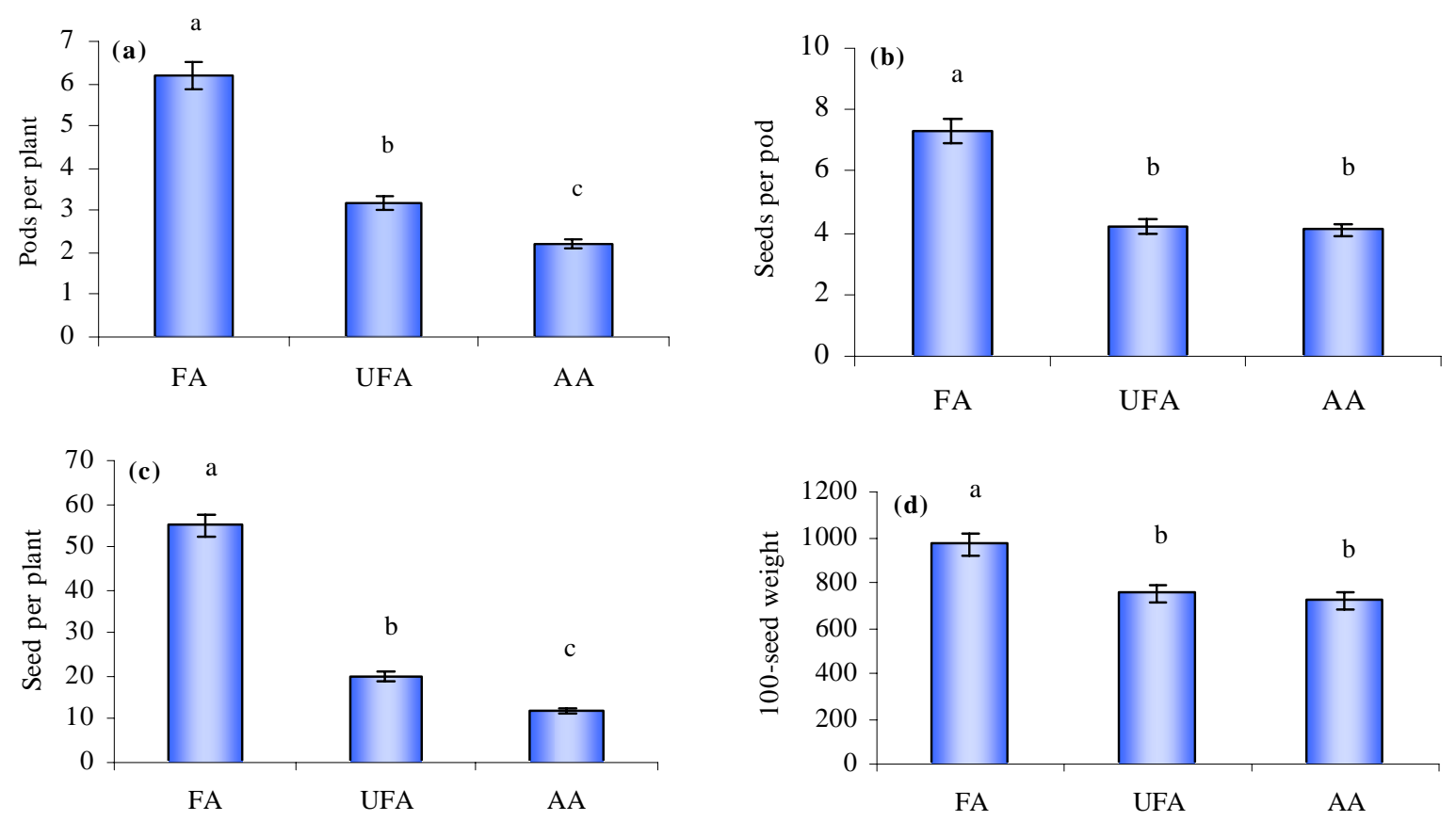

Fig. 7: Various yield parameters in mungbean after various air treatments in open-top chamber system. Data bars with different letters are significantly different at $\mathrm{P}<0.05$

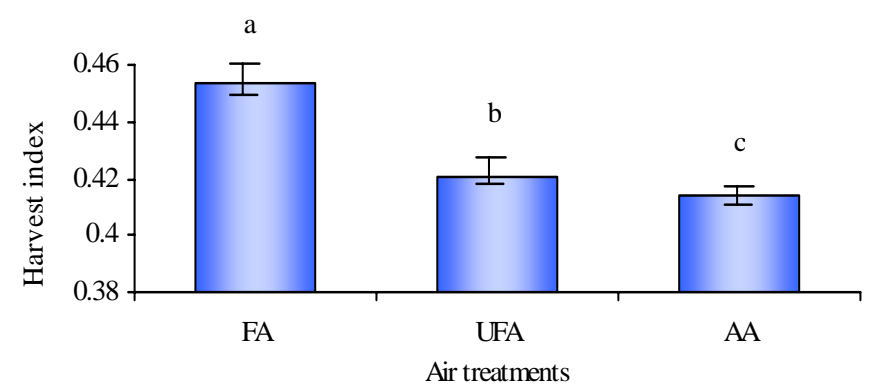

Fig. 8: Harvest index of mungbean plants after various air treatments at final harvest. Data bars with different letters are significantly different at $\mathrm{P}<0.05$ according to DNMRT

(a)

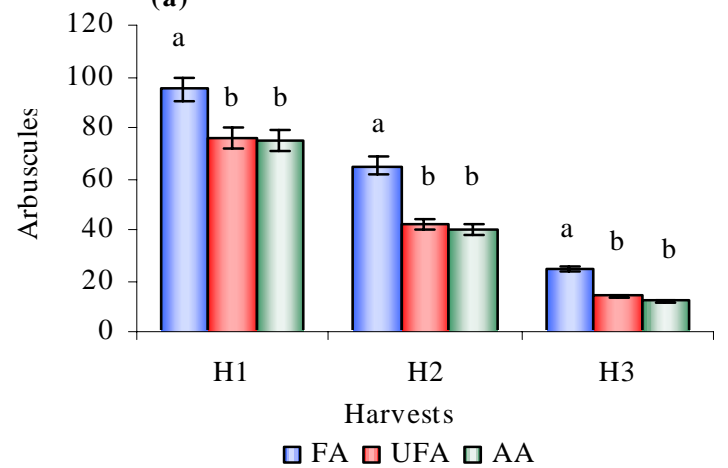

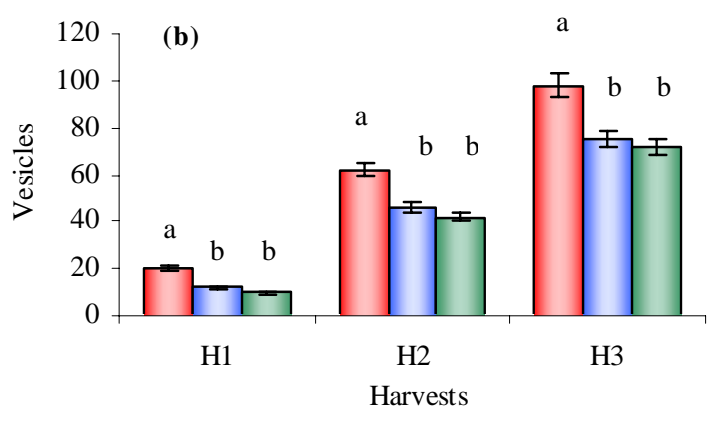

$\square$ FA $\square$ UFA $\square$ AA

Fig. 9: Percentage of arbuscules and vesicles in root cortex of mungbean plants after various air treatments in open-top chamber system. Data bars with different letters are significantly different at $\mathrm{P}<0.05$ 
The concentration of polluting gases, or their solutions, to which the plants were exposed were highly variable, depending on wind direction, rainfall, and sunlight. Polluting gases, such as $\mathrm{SO}_{2}$ and $\mathrm{NO}_{2}$ enter leaves through stomata, following the same diffusion pathway as $\mathrm{CO}_{2} \cdot \mathrm{NO}_{\mathrm{x}}$ dissolves in cells and gives rise to nitrite ions $\left(\mathrm{NO}_{2}\right.$, which are toxic at high concentrations) and nitrate ions $\left(\mathrm{NO}_{3}\right)$ that enter into nitrogen metabolism as if they have been absorbed through the roots. In some cases, exposure to pollutant gases, particularly $\mathrm{SO}_{2}$, causes stomatal closure, which protects the leaf against further entry of the pollutant but also curtails photosynthesis. In the cells, $\mathrm{SO}_{2}$ dissolves to give bisulfite and sulfite ions; sulfite is toxic, but at low concentration it is metabolized by chloroplast to sulfate, which is not toxic. At sufficiently low concentration, bisulfite and sulfite are effectively detoxified by plants, and $\mathrm{SO}_{2}$ air pollution then provides a sulfur source for the plant. Dissolution of $\mathrm{NO}_{\mathrm{x}}$ and $\mathrm{SO}_{2}$ in water droplets in the atmosphere causes the $\mathrm{pH}$ of the rain to decrease to 3 to 4 or some times up to 1.7 as compared to unpolluted rain, which has $\mathrm{pH}$ in the range of 5.6. This $\mathrm{H}^{+}$addition into the soil in the form of wet and dry deposition can result in the release of ammonium ions from soil minerals, causing aluminum toxicity. Air pollution is considered to be a major factor in the decline of forests in heavily polluted areas of Europe and North America, (Tiaz and Zeiger, 2006). In urban areas, these polluting gases may be present in such a high concentration that they cannot be detoxified rapidly enough to avoid injury. Ozone is presently considered to be the most damaging air pollutant in North America (Heagle, 1989; Krupa, et al., 1995). It has been estimated that where ever the mean daily $\mathrm{O}_{3}$ concentration reaches 40,50 , or $60 \mathrm{ppb}$ (parts per billion, or per $10^{9}$ ), the combined yields of soybean, maize, winter wheat, and cotton would be decreased by 5,10 , and $16 \%$ respectively. Ozone is highly reactive and binds to plasma membrane and it alters metabolism. As a result, stomatal apertures are poorly regulated, chloroplast thylakoid membranes are damaged, rubisco is degraded, and photosynthesis is inhibited. Ozone reacts with $\mathrm{O}_{2}$ and produces reactive $\mathrm{O}_{2}$ species, including hydrogen peroxide $\left(\mathrm{H}_{2} \mathrm{O}_{2}\right)$, superoxide $\left(\mathrm{O}_{2}\right)$, single oxygen $\left(\mathrm{O}_{2}\right)$, and the hydroxyl radicle $(\mathrm{OH})$. The denatured proteins, damage nucleic acids and thereby give rise to mutations, and cause lipid peroxidation, which breaks down lipids in membranes. Many deleterious changes in metabolism caused by air pollution precede external symptoms of injury, which appear only at much higher concentrations. For example, when plants are exposed to air containing $\mathrm{NO}_{\mathrm{v}}$, lesions on leaves appear at an $\mathrm{NO}_{\mathrm{x}}$ concentration of 5 $\mathrm{mL} / \mathrm{L}$, but photosynthesis starts to be inhibited at a concentration of only $0.1 \mathrm{~mL} / \mathrm{L}$. These low, threshold concentration refer to the effects of single pollutant. However, two or more pollutants acting together can have a synergistic effect, produce damage at lower concentrations than if they were acting separately. In addition, vegetation weakened by air pollution can become more susceptible to invasion by pathogens and pests (Moldau, 1999). The results of the present study also show that both fresh and dry weights of FA plants were higher than their UFA and AA counterparts. This may be considered as a reflection of more vigorous growth of FA plants through out the experimental period. These results are also inline with the previous studies carried out in North America (Kats, et al., 1985; Amundson, et al., 1987), Europe (Adaros, et al., 1991; Bender, et al., 1991; Pleijel, et al., 1991), Japan (Nouchi, et al., 1995) and Pakistan, (Wahid, et al., 1995a, 1995 b). The difference in growth between UFA and AA plants may be considered due to dust particles. Although dust pollution is of localized importance near roads, quarries, cement works, and other industrial areas. Apart from screening out sunlight, dust on leaves blocks stomata and lowers their conductance to $\mathrm{CO}_{2}$ simultaneously interfering with photosystem II, (Taiz and Zeiger, 2006). In the present study, the results presented for mungbean are quite in line with those obtained by Wahid et al., (1995a and 1995b). Particularly in terms of yield the total grain weight per plant is reduced which may be attributed to the number of ears per plant, number of grains per ear and number of grains per plant. This is consistent with the observations by Heagle, et al., (1979), Mulchi, et al., (1988), Pleijel, et al., (1991), Fuhrer, et al., (1997) and Wahid, et al., (1995a and 1995b). However, the results cannot be compared with those of the fumigation studies (Wahid, et al., 1995a and 1995b). Further more the pants in the present study were grown in pots which also makes the comparison with other work (conducted in the field) difficult. It has been indicate by Skarby, et al., (1998) that pot-grown plants are less sensitive to $\mathrm{O}_{3}$ than those in the field, possibly due to reduced nutrients and water status. Thus, it can be concluded that pollutants has reduced plant growth of mycorrhizal plants but as Ho and Trappe (1984) have said that the growth reduction is even greater in non-mycorrhizal plants. 
Response of arbuscular mycorrhizal mungbean plants to...

Table 2: Effect of air filtration on species of chlamydospores of arbuscular mycorrhizal fungi of mungbean plants at the time of mid-season and final harvest stage in various air and soil treatments

\begin{tabular}{|c|c|c|}
\hline Harvests & $\begin{array}{c}\text { Air } \\
\text { treatments }\end{array}$ & AM spore types \\
\hline \multirow{3}{*}{ Harvest-I } & FA & $\begin{array}{l}19 \text { spore types of AM recovered: } \\
\text { Acaulospora bireticulata, Glomus aggregatum, G. albidum, G. caledonicum, G. cerebriforme, G. } \\
\text { clarum, G. constrictum, G. deserticola, G. dimorphicum, G. fasciculatum, G. geosporum, G. } \\
\text { intraradices, G. microaggregatum, G. microcarpum, G. mosseae, G. tenue, Sclerocystis } \\
\text { microcarpus, S. pakistanica and Scutellospora pellucida }\end{array}$ \\
\hline & UFA & $\begin{array}{l}15 \text { spore types of AM recovered: } \\
\text { Acaulospora bireticulata, Glomus aggregatum, G. clarum, G. constrictum, G. deserticola, G. } \\
\text { fasciculatum, G. geosporum, G. intraradices, G. microaggregatum, G. microcarpum, G. mosseae, } \\
\text { G. tenue, Sclerocystis microcarpus, S. pakistanica and Scutellospora pellucida }\end{array}$ \\
\hline & AA & $\begin{array}{l}16 \text { spore types of AM recovered: } \\
\text { Acaulospora bireticulata, Glomus aggregatum, G. clarum, G. constrictum, G. deserticola, G. } \\
\text { dimorphicum, G. fasciculatum, G. geosporum, G. intraradices, G. microaggregatum, G. } \\
\text { microcarpum, G. mosseae, G. tenue, Sclerocystis microcarpus, S. pakistanica and Scutellospora } \\
\text { pellucida }\end{array}$ \\
\hline \multirow{3}{*}{ Harvest-II } & FA & $\begin{array}{l}20 \text { spore types of AM recovered: } \\
\text { Acaulospora bireticulata, A. rehmii, Glomus aggregatum, G. albidum, G. caledonicum, G. } \\
\text { cerebriforme, G. clarum, G. constrictum, G. deserticola, G. dimorphicum, G. fasciculatum, G. } \\
\text { geosporum, G. intraradices, G. microaggregatum, G. microcarpum, G. mosseae, G. tenue, } \\
\text { Sclerocystis microcarpus, S. pakistanica and Scutellospora pellucida }\end{array}$ \\
\hline & UFA & $\begin{array}{l}13 \text { spore types of AM recovered: } \\
\text { Acaulospora bireticulata, Glomus aggregatum, G. clarum, G. constrictum, G. deserticola, G. } \\
\text { fasciculatum, G. intraradices, G. microaggregatum, G. microcarpum, G. mosseae, G. tenue, } \\
\text { Sclerocystis microcarpus and S. pakistanica. }\end{array}$ \\
\hline & AA & $\begin{array}{l}15 \text { spore types of AM recovered: } \\
\text { Acaulospora bireticulata, Glomus aggregatum, G. clarum, G. constrictum, G. deserticola, G. } \\
\text { fasciculatum, G. geosporum, G. intraradices, G. microaggregatum, G. microcarpum, G. mosseae, } \\
\text { G. tenue, Sclerocystis microcarpus, S. pakistanica and Scutellospora pellucida }\end{array}$ \\
\hline \multirow{3}{*}{ Harvest-III } & FA & $\begin{array}{l}24 \text { spore types of AM recorded: } \\
\text { Acaulospora bireticulata, A. rehmii, Gigaspora decipiens, Glomus aggregatum, G. albidum, G. } \\
\text { caledonicum, G. cerebriforme, G. clarum, G. constrictum, G. deserticola, G. dimorphicum, G. } \\
\text { fasciculatum, G. geosporum, G. halonatum, G. intraradices G. leptotichum, G. microaggregatum, } \\
\text { G. microcarpum, G. monosporum, G. mosseae, G. tenue, Sclerocystis microcarpus, S. pakistanica } \\
\text { and Scutellospora pellucida }\end{array}$ \\
\hline & UFA & $\begin{array}{l}14 \text { spore types of AM recorded: } \\
\text { Acaulospora bireticulata, Glomus aggregatum, G. clarum, G. constrictum, G. deserticola, G. } \\
\text { fasciculatum, G. geosporum, G. intraradices, G. microaggregatum, G. microcarpum, G. mosseae, } \\
\text { G. tenue, Sclerocystis microcarpus and S. pakistanica. }\end{array}$ \\
\hline & AA & $\begin{array}{l}14 \text { spore types of AM recorded: } \\
\text { Acaulospora bireticulata, Glomus aggregatum, G. clarum, G. constrictum, G. deserticola, G. } \\
\text { fasciculatum, G. geosporum, G. intraradices, G. microaggregatum, G. microcarpum, G. mosseae, } \\
\text { G. tenue, Sclerocystis microcarpus and S. pakistanica. }\end{array}$ \\
\hline
\end{tabular}

Table 3: Effects of air filtration on nodule biomass and nitroginase activity

\begin{tabular}{clllll}
\hline $\begin{array}{c}\text { Sr. } \\
\text { No. }\end{array}$ & \multicolumn{1}{c}{ Parameter } & \multirow{2}{*}{ Harvest } & \multicolumn{3}{c}{ Air treatments } \\
\hline 1. & Fresh weight of & $1^{\text {st. }}$ & $145.34 \mathrm{a}$ & $82.40 \mathrm{~b}$ & $80.35 \mathrm{~b}$ \\
& nodules/plant (mg) & $2^{\text {nd. }}$ & $180.67 \mathrm{a}$ & $122.5 \mathrm{~b} 6$ & $121.60 \mathrm{~b}$ \\
& & $3^{\text {rd. }}$ & $265.86 \mathrm{a}$ & $137.70 \mathrm{~b}$ & $130.55 \mathrm{~b}$ \\
2. & Dry weight of & $1^{\text {st. }}$ & $10.04 \mathrm{a}$ & $3.52 \mathrm{~b}$ & $3.48 \mathrm{~b}$ \\
& nodules/plant (mg) & $2^{\text {nd. }}$ & $21.63 \mathrm{a}$ & $8.55 \mathrm{~b}$ & $7.94 \mathrm{~b}$ \\
& $3^{\text {rd. }}$ & $31.34 \mathrm{a}$ & $12.05 \mathrm{~b}$ & $11.45 \mathrm{~b}$ \\
3. & Nitroginase activity/ & $1^{\text {st. }}$ & $2.225 \mathrm{a}$ & $0.993 \mathrm{~b}$ & $0.985 \mathrm{~b}$ \\
& plant (u mole $\mathrm{C}_{2} \mathrm{H}_{2} / \mathrm{g}$ & $2^{\text {nd. }}$ & $3.420 \mathrm{a}$ & $1.122 \mathrm{~b}$ & $1.103 \mathrm{~b}$ \\
& weight of nodules/h) & $3^{\text {rd. }}$ & $4.1901 \mathrm{a}$ & $1.832 \mathrm{~b}$ & $1.804 \mathrm{~b}$ \\
\hline
\end{tabular}

Air filtration also resulted in better reproductive growth in plants of FA treatment. Significantly high flower production by FA plants ended up with appreciably high yields than plants of other air treatments, (Mathy, 1993; Wahid, et al., 1995a, 1995b). Similarly, a very positive trend was noticed in nodulation and $\mathrm{N}$-fixation ability of mungbean and soybean plants in filtered air. In the case of soybean, the number of nodules per plant, fresh weight of nodule per plant, oven dry weight of nodules per plant and rate of $\mathrm{N}$ fixation was significantly high in FA plants following a 


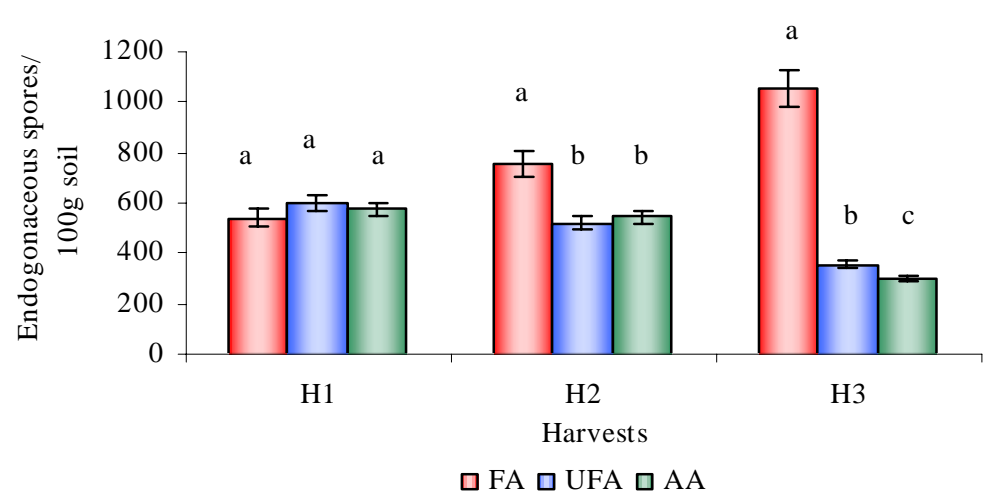

Fig. 10: Percentage of arbuscules and vesicles in root cortex of mungbean plants after various air treatments in open-top chamber system. Data bars with different letters are significantly different at $\mathrm{P}<0.05$

reduction in UFA and AA plants. Earlier studies have shown reduced plant growth and biomass in soybean cultivars due to air pollution, Sabaratnum and Gupta, 1988; Kohut, et al., 1986; Heggestad and Lee, 1990; Mulchi, et al., 1988). However, there is only one research paper as yet regarding the interaction between Glomus geosporum (a AM forming fungus) and exposure of soybean to ozone, (Brewer and Heagle 1983). There are indeed very few studies of interactions/ or involvement of fungi in pollution studies, (Nasim, et al., 1995; Krupa, et al., 1995). The present study was therefore undertaken to review the effects of the gaseous pollutants in causing reduction not only in plant growth and yield but also affecting the development of vesicular arbuscular mycorrhizal association in roots of mungbean. This study is in line with those of Brewer and Heagle (1983), Reich, et al., (1988), Ho and Trappe (1984) and Kraigher, et al., (1996). In the case of ectomycorrhizae (EM) there are evidences of a decline in the frequency of EM forming fungi in Netherlands associated with pollutants like sulfurdioxide $\left(\mathrm{SO}_{2}\right)$ and ammonia, (Termorshuzen and Schaffers, 1987). There is also one report by Shaw, et al., (1992), of reduced EM formation in conifers in increased $\mathrm{SO}_{2}$ and $\mathrm{O}_{3}$. Human activities are changing the environment in which mycorrhizal roots function on a global as well as on local scale. Mycorrhizal associations being largely dependent on the photosynthates of the host may indirectly be affected by reduced rates of photosynthesis, (Graham, et al., 1982). According to the study of Graham, et al., (1982), reduced photon irradiances adversely affected the frequency of arbuscules and vesicles formed by arbuscular mycorrhizal fungi. In the case of ambient air pollution, $\mathrm{O}_{3}$ inhibits the rate of photosynthesis ending up with chlorosis and necrosis of leaves (Heath, et al., 1982; Heath and Tylor, 1997; Heath, 1988). These indirect effects of pollutant in reducing photosynthesis and hence carbon allocation to the root system may also inhibit mycorrhizal development. This finally results in reduced growth and yield of plants. The study however showed that mycorrhizal plants had significantly high values for growth and yield parameters than non-mycorrhizal plants in all air treatments. In all respects, FA plants had significantly high values for different parameters than UFA and AA plants. (Nasim and Zahoor, 1996). There is an apparent lack of host specificity among AM fungi but some of these may be associated with a certain host plant, (Fox and Spasoff, 1971). Most taxa of AM fungi forming spores are in Glomus (Morton, 1988). The existence of Glomus as the dominant genus in the root zone indicates either the influence of the soil or the plant type, (Schenck and Kinloch, 1980, Nasim and Iqbal, 1991). The present study is also in line with the previous investigations indicating the presence of Glomus as a dominant and most resistant genus. The species, which were sensitive to air pollution, disappeared while the resistant species remained there and sporulated. Among sensitive species were Acaulospora rehmii, Gigaspora decipiens, Glomus albidum, G. caledonium, G. dimorphicum, G. leptotichum, and Scutellospora pellucida. The absence of spores of these AM species from normal mycofloral composition in the rhizosphere of mungbean may be considered as an alarming sign indicating the pollution environment. This attempt is in line with the study of Kraigher, et al., (1996) which they carried out for ectomycorrhiza forming fungi. 
Nothing has been said about the N-fixation ability of the plants facing the air pollution stress. The present study documents the decline in all parameters related to nodule number biomass and nitroginase activity. The integrated effects result into cascading effects inturn affecting the $\mathrm{N}$-fixation ability of mungbean. However further fumigation and filtered air studies on invitro behaviour of Rhizobium are needed. The study can be concluded by stating that the test plants like mungbean are typically mycotrophic and also respond strikingly to the air treatments. The results have also shown that the pollutants reduced plant growth of mycorrhizal plants but growth reduction was even greater in non-mycorrhizal plants confirming the inferences made by Ho and Trappe, (1984) and Brewer and Heagle (1983). Relatively long-term experiments at appropriate concentration of pollutants are necessary to establish the real impact of air pollution on vegetation. The reactions of test plants to high concentration of pollutants in short-term experiments may overwhelm the plant's defense mechanism and may provoke abnormal symptoms. As air pollutant levels are likely to continue to rise over the coming decades in many developing countries including Pakistan, therefore further investigations are immediately needed to screen pollution tolerant/ resistant mycorrhizal species for all the important crop plants. It is also needed to evaluate the possible role of mycorrhiza in inducing resistance in plants to air pollution in developing countries like Pakistan.

\section{REFERENCES}

Adarose, G.; Weigel; Jager, H.J., (1991). Concurrent exposure to $\mathrm{SO}_{2}$ and or $\mathrm{NO}_{2}$ alters growth and yield responses of wheat and barley to low concentration of $\mathrm{O}_{3}$. New Phytologist, 118, 581-591.

Allen, M.F.; Rincon, (2003). The changing global environment and the low land Maya: Past patterns and current dynamics. Gomez-Pompa, A., M. F. Allen, S. Fedick, and J. J. JimenezOsornio. Lowland Maya Area: Three mellinia at the humanwildland interface.Haworth Press, NY., 3-30

Amundson, R.G.; Raba, R.M.; Schoettle, A.W.; Kohut, R.J.; Reich, P.B., (1987). Correlative reductions in whole plant photosynthesis and yield of winter wheat caused by ozone. Phytopath., 77, 75-79.

Atkins, D.H.F.; Healy, C.; Tarremt, J.B., (1987). The use of simple diffusion tubes for the treatment of nitrogen dioxide levels in homes using gas and electricity for cooking. Report R9184. AERE, Harwell.

Bell, J.N.B.; Ashmore, M.R., (1986). Design and construction of chambers and methods of filtration. In: Microclimate and Plant Growth in Open-top chambers. CEC, Air Pollut. Res. 5, 1-13.
Bender, J.; Weigel, H.J.; Jager, H.J., (1991). Response of nitrogen metabolism in beans (Phaseolus vulgaris L.) after exposure to ozone and nitrogen dioxide, alone and in sequence. New Phytologist, 119, 261-267.

Berreck M.; Haselwandter, K., (2001). Effect of the arbuscular mycorrhizal symbiosis on uptake of cesium and other cations by plants. Mycorrhiza., 10(6), 275-280.

Brewer, P.F.; Heagle, A.S., (1983). Interaction between Glomus geosporum and exposure of soybean to ozone or simulated acid rain in the field. Phytopath., 73, 1035-1040.

Burroughs, W.J., (2001). Climate Change: A multidisciplinary Approach, Cambridge University Press, Cambridge, UK., 298.

Cairney, J.W.G.; Meharg, A.A., (1999). Influences of anthropogenic pollution on mycorrhizal fungal communities. Environ. Pollut., 106, 169-182.

Carver R.H.; Nash, J.G., (2000). Doing data analysis with SPSS 10.0. Brooks/Cole, Duxbury, UK.

Castagna, A.; Nali, C.; Ciompi, S.; Lorenzini, G.; Soldatini, G.F.; Ranieri., (2001). Ozone exposure affects photosynthesis of pumpkin (Cucurbita pepo) plants. New Phytologist, 152, 223-229.

Chaudhry, T.M.; Hayes, W.J.; Khan, A.G.; Khoo, C.S., (1998). Phytoremediation-Focusing on accumulator plants that remediate metal contaiminated soils. Aust. J. Ecotox., 4, $37-51$.

Duckmanton L.; Widden, P., (1994). Effect of ozone on the development of vesicular-arbuscular mycorrhizae in sugar maple saplings. Mycologia 86, 181-186.

Egerton-Warburton, L.M.; Graham, R.C.; Allen, E.B.; Allen, M.F., (2001). Reconstruction of the historical changes in mycorrhizal fungal communities under anthropogenic nitrogen deposition.

Egerton-Warburton, L.M.; Allen, E.B.; Allen, M.F., (2002). Mycorrhizal fungal communities: Their organization role and conservation in ecosystem under elevated atmospheric CO2 and anthropogenic nitrogen deposition. In: K.Sivasithamparam, K. W. Dixon and R. L. Barrett (eds.) Microorganisms in Plant Conservation and Biodiversity. Kluwer Academic Press. 19-43.

Envirinmental Protection Agency, (USEPA), (1996). The air quality criteria for ozone and other photochemical oxidants. EPA-600/P-93/004 a, b, c, f. Reasearch Triangle Park, NC, USA: National Centre for Environmental Assessment.

Fitter, A.H.; Heinemeyer, A.; Staddon, P.L., (2000). The impact of elevated $\mathrm{CO}_{2}$ and global climate change on arbuscular mycorrhizas: a mycocentric approach. New Phytologist, 147, 179-187.

Fox, J.A.; Spasoff, L., (1971). Host range of Endogone gigantea. Proctors of Veterinary Sciences, 23, 121-124.

Fuhrer, J.; Skarby, L.; Ashmore, M.R., (1997). Criticle levels for ozone Effects on vegetation in Europe. Environ. Pollut., 97, 91-106.

Gerdemann, J.W.; Nicolson, T.H., (1963). Spores of mycorrhizal 'Endogone' extracted from soil by wet sieving and decanting. Trans. British Mycologic. Soc., 84: 679-684.

Graham, J.H.; Leonard, R.T.; Menge, J.R., (1982). Interaction of light intensity and soil temperature with phosphorus inhibition of vesicular arbuscular mycorrhiza formation. New Phyto., 91, 683-690.

Heagle, A.S., (1989). Ozone and crop yield. An. Rev. Plant Patho., 27, 397-423. 
Heagle, A.S.; Philbeck, R.B.; Rogers, H.H.; Letchworth, M.B., (1979). Dispensing and monitoring ozone in open-top field chambers for plant-effects studies. Phytopatho., 69, 15-20.

Heath, R.L., (1980). Initial events in injury to plants by air pollutants. Rev. Plant Physio., 31, 395-431.

Heath, R.L., (1988). Biochemical mechanisms of pollutant stress, in: W. W. Heck, O. C. Taylor, D. T. Tingey (Eds.), Assessment of Crop Loss from Air Pollutant, Elsevier, Applied Science, London, 259-286.

Heath, R.L.; Tylor Jr., G.E., (1997). Physiological processes and plant responses to ozone exposure, in: H. Sandermann Jr, A. R. Wellburn, R. L. Heath (Eds.), Forest Decline and Ozone, Springer-Verlag, Berlin, 317.

Heath, R.L.; Frederick, P.E.; Cahmikias, P.E., (1982). Ozone inhibition of photosynthesis in Chlorella sorokiniana. Plant Physio., 69, 229-233.

Heggestud, H.E.; Lee, E.H., (1990). Soybean root distribution, top growth and yield responses to ambient ozone and soil moisture stress when grown in soil columns in greenhouse. Environ. Pollut., 65, 195-207.

Ho, I.; Trappe, J.M., (1984). Effects of ozone exposure on mycorrhiza formation and growth of Festuca arundinacea. Environ. Exp. Bot., 24 (1), 71-74.

Iqbal, S.H.; Nasim, G., (1991). Are under ground non-root portions of tropical plants vesicular arbuscular mycorrhizal? Trans. Mycologic. Soc.Japan, 32, 467-476.

Iqbal, S.H.; Nasim, G., (1986). Vesicular arbuscular mycorrhiza in roots and other underground portion of Curcuma longa. Biologia, 32, 223-228.

Kats, G.; Dawson, P.J.; Bytnerowicz, A.; Wolf, J.W.; Thompson, C.R. Olszyk, D.M., (1985). Effect of ozone or sulfur dioxide on growth and yield of rice. Agric. Ecosys. Environ., 14, 103-117.

Khan, A.G.; Kuek, C.; Chaudhry, T.M.; Khoo, C.S.; Hayes, W.J., (2000). Role of plants, mycorrhizae and phytochelators in heavy metal contaminated land remediation. Chemos., 41, 197-207.

Kohut, R.J.; Amundson, R.G.; Laurence, J.A.; Colavito, L.; Van Leuken, P.; King, P., (1986). Effect of ozone and sulfur dioxide on yield of winter wheat. Phytopathology, 77, 7174.

Kraigher, H.; Batic, F.; Agerer, R., (1996). Types of ectomycorrhizae and mycobioindication of forest site pollution. Phyton. Ann. Reebot., 36, 115-120.

Krupa, S.V.; Gruenhage, L.; Jaeger, H.; Manning, W.J.; Hanewald, A.H., (1995). Ambient ozone and adverse crop response: A unified view of cause and effect. Environ. Pollut., 87, 119-126.

Lefohn, A.S.; Jackson, W.; Shadwick, D.S.; Knudsen, H.P., (1997). Effect of surface ozone exposures on vegetation growth in the southern Appalachian mountains: identification of possible areas of concern. Atmos. Environ., 11, 1695-1708.

Leyval, C.; Haselwandter, K.; Turnau, K., (1997). Effect of heavy metal pollution on mycorrhizal colonization and function. Physio. Eco. Appl. Aspec. Myco., 7, 139-153.

Mathy, P., (1993). Effects of air pollution on agricultural crops in Europe. Air pollution Research Report No. 46. Commission of the European Communities, Brussels, Belgium.

McCool, P.M.; Menge, J.A.; Taylor, O.C., (1982). Effect of ozone injury and light stress on response of tomato to infection by the vesicular-arbuscular mycorrhizal fungus, Glomus-fasciculatus. J. Am. Soc. Hort. Sci., 107, 839-842

McCool, P.M., Menge, J.A., Taylor, O.C., (1983). Influence of ozone on carbon partitioning in tomato-potential role of carbon flow in regulation of the mycorrhizal symbiosis under conditions of stress. New Phytol., 94, 241-247.

McCool, P.M., (1984). Interaction of ozone and mycorrhizal fungi on tomato as influenced by fungal species and host variety. Soil Bio. Biochem., 16, 425

McCool, P.M.; Menge, J.A.; Taylor, O.C., (1979). Effects of ozone and $\mathrm{HCl}$ gas on the development of the mycorrhizal fungus Glomus fasciculatum and growth of troyer citrinage. J.Am. Soc. Hort. Sci., 104, 151-154.

McCrady, J.K.; Andersen, C.P., (2000). The effect of ozone on below-ground carbon allocation in wheat. Environ. Pollut., 107, 465-472

Miller, J.E.; Shafer, S.R.; Schoeneberger, M.M.; Pursley, W.A.; Horton, S.J.; Davey, C.B., (1997). Influence of a mycorrhizal fungus and/or rhizobium on growth and biomass partitioning of subterranean clover exposed to ozone. Water Air and Soil Pollut., 96, 233-248

Moldau, H., (1999). Ozone detoxification in the mesophyll cell wall during a stimulated oxidative burst, Free Radical Research, 31, 19-24.

Morton, J.B., (1988). Taxonomy of VA mycorrhizal fungi: classification, nomenclature, and identification. Mycotaxon, 32, 267-324.

Mulchi, C.L., Lec, E., Tuthill, K., Olinick, E.V., (1988). Influence of ozone stress on growth processes, yields and grain quality characteristics among soybean cultivars. Environ. Pollution, 53, 151-169.

Nasim, G.; Iqbal, S.H., (1991). Fate of Endogonaceous spores in soil. Trans. Myco. Soc. Japan, 32, 517-522.

Nasim, G. and Iqbal, S.H., (1991). Species of Glomus associated with non-root portions of some rhizomatous plants and characteristics of their mycorrhizae. Trans. Myco. Soc. Japan, 32, 541-545.

Nasim, G., Fatima, A., Shaheen, M. Bajwa, R., (1992). Effect of six different inocula on growth and VAM status of wheat (Triticum aestivum L. Pak 81). J. Sys. Exp. Bio., 2(1), 4768.

Nasim, G.; Bajwa, R., (2005). Glomalean spores associated with major cereals I-Wheat Caderno Pesquisa Serie Biologia, 17(1), 137-154.

Nasim, G.; Iqbal, S.H., (1991). Species of Glomus associated with non-root portions of some rhizomatous plants and characteristics of their mycorrhizae. Trans. Myco. Soc. Japan,Trans. Myco. Soc. Japan, 32, 541-545.

Nasim, G.; Zahoor, R., (1996). Seasonal spore dynamics of six Glomus species and their interspecific interactions in a wheat field. Sci. Sindh, 3, 73-82.

Nasim, G.; Saeed, S.; Wahid, A.; Bajwa, R., (1995). Impact of air pollution on growth, yeild and vesicular arbuscular mycorrhizal status of wheat, Triticum aestivum var. Pak. 81. Biota, 1(1 and 2), 91-111.

Nouchi, I.; Ito, O.; Harazano, Y.; Kouchi, H., (1995). Acceleration of $\mathrm{C}^{13}$ labelled photosynthates from leaves to panicles in rice plants exposed to chronic ozone at the reproductive stage. Environ. Pollut., 88, 253-260.

Oliveira, R.S.; Dodd, J.C.; and Castro, P.M.L., (2001). The mycorrhizal status of Phragmites australis in several polluted soils and sedimentsof an industrial region of Northern Portugal. Mycorrhiza, 10(5), 241-247. 
Phillips, J.M.; Hayman, D.S.; (1970). Improved procedures for clearing roots and staining parasitic and vesiculararbuscular fungi for rapid assessment of infections. Tran. Br. Мyco. Soc., 55, 158-160.

Pleijel, H.; Skarby, L.; Walin, G.; Sellden, G., (1991). Yield and grain quality of spring wheat (Triticum aestivum cv. Drabant) exposed to different concentration of ozone in open-top chambers. Environ. Pollut., 69, 151-168

Proceedings of the Royal Society of London Series B-biological Sciences, 268: 2479-2484

Ranieri, A.; D’Urso, G.; Nali, C.; Baldan, B.; Lorenzini, G.; Soldatini, G.F., (1996). Ozone stimulates apoplastic systems in pumpkin leaves. Physio. Plants, 97, 381-387.

Ranieri, A.; Serini, R.; Castagna, A.; Nali, C.; Baldan, B.; Lorenzini, G.; Soldatini, G.F., (2000). Differential sensitivity to ozone in two poplar clones: analysis of thylakoid pigmentprotein complexes. Physio. Plant., 110, 181-188.

Reich, P.B.; Schoettle, A.W.; Amundson, R.G., (1988). Effects of ozone and acid rain on white pine seedlings grown in five soils. II. Mycorrhizal infections. Canadian J.Bot., 66, 1510-1516.

Rosner, R., (2000). Fundamentals of Biostatistics, Fifth edition, Brooks/Cole, Duxbury, UK.

Saltzman, B.E.; Gilbert, K., (1959). Iodometric microdetermination of organic oxidants and ozone. Anal. Chem., 31, 1914-1920.

Samuelson, L.; Kelly, J.M., (2001). Scalling ozone effects from seedlings to forest trees. New Phyt., 149, 21-41.

Samuelson, L.; Kelly, J.M., (2001). Scalling ozone effects from seedlings to forest trees. New Phytologist, 149, 21-41.

Schenck, N. C. and Kinlock, R. A. (1980). Incidence of mycorrhizal fungi on six fields in monoculture on a newly cleared woodland site. Mycologia, 72: 445-456.

Schenck, N.C.; Perez, Y., (1990). Manual for the Identification of VA mycorrhizal Fungi. Synergistic Publishers, Gainesville, Florida. 286.

Shafer, S.R.; Schoeneberger, M.M., (1991). Mycorrhizal mediation of plant-response to atmospheric change - air- quality concepts and research considerations. Environ. Pollut., 73, 163-177

Shaw, P.J.A.; Dighton, J.; Poskitt, J., (1992a). Studies on the mycorrhizal communities infecting trees in the Liphook forest fumigation experiment. Forest Eco. Manag., 8, 6775.

Sinclair, T.R., (1998). Historical changes in harvest index and crop nitrogen assimilation. Crop. Sci., 38(3), 638-643.

Skarby, L., Ro-Poulsen, H,. Wellburn, F. A. M. and Sheppard, L. J. (1998). Impact of ozone on forests: a European perspective. NewPhytologist, 139: 109-122.

Steel, R.G.D.; Torrei, V.J.H., (1980). Principles and procedures of statistics. McGraw Hill, New York.

Subaratrum, S.; Gupta, G., (1988). Effect of nitrogen dioxide on biochemical and physiological characteristics of soybean. Environ. Pollut., 19, 1-10.

Taiz, L.; Zeiger, E., (2006). Plant Physiology. Fourth Edition, Sinuaer Associates, Inc., Publishers Sunderland, Massachusetts. 792.

Toermorshuizen, A.J.; Shaffers, A.P., (1987). Occurrence of carpophores of ectomycorrhizal fungi in selected stands of Pinus sylvestris in the Netherlands in relation to stand vitality and air pollution. Plant and soil, 104, 209-217.

Treseder, K.K.; Allen, M.F., (2002). Direct nitrogen and phosphorus limitations of limitations of arbuscular mycorrhizal fungi: a model and field test. New Phytologist, 155(3), 507-515.

Wahid, A.; Maggs, R.; Shamsi, S.R.A.; Bell, J.N.B.; Ashmore, M. R. (1995a). Air pollution and its impacts on wheat yield in the Pakistan, Punjab. Environ. Pollut., 88, 147-154.

Wahid, A.; Maggs, R.; Shamsi, S.R.A.; Bell, J.N.B.; Ashmore, M.R., (1995b). Effects of air pollution on rice yield in the Pakistan Punjab, Environ. Pollut., 90(3), 323-329.

Yoshida, L.C.; Gamon, J.A.; Andersen, C.P., (2001). Differences in above- and below-ground responses to ozone between two populations of a perennial grass. Plant Soil., 233, 203-211.

\section{AUTHOR (S) BIOSKETCHES}

Nasim, G., M.Sc. and Ph.D., is an assistant professor at the Department of Mycology and Plant Pathology, University of the Punjab, Lahore, Pakistan. Currently she is doing her post doc. in the Department of Plant Sciences, University of Tennessee, Knoxville, USA. Email: gnasim@utk.edu

Bajwa, R., M.Sc. and Ph.D., is a professor and chairman at the Department of Mycology and Plant Pathology, University of the Punjab, Lahore, Pakistan. Email: rukhsana.bajwa@gmail.com

Hakeem, A., M.Sc., is an employee at the Department of Agriculture, Pakistan. Currently he is doing his Master degree in the Department of Entomology and Plant Pathology, University of Tennessee, Knoxville, USA. Email: ahakeem@utk.edu

This article should be referenced as follows:

Nasim, G.; Bajwa, R.; Hakeem, A., (2007). Response of arbuscular mycorrhizal mungbean plants to ambient air pollution. Int. J. Environ. Sci. Tech., 4 (3), 295-310. 